\title{
An Overview Of Fiduciary Standards And Suitability For Financial Planning Students
}

James T. Chong, California State University Northridge, USA

Penelope R. Jennings, California State University Northridge, USA

G. Michael Phillips, California State University Northridge, USA

\begin{abstract}
Financial planning is an interdisciplinary field including finance and business law topics. Consequently, standard pedagogical resources often omit topics that fall between these fields. To address a key gap in educational materials for financial planning students and faculty, this article reviews recent regulatory developments for financial planning students, including strengthened fiduciary standards and FINRA suitability requirements. The discussion introduces FINRA 2090, FINRA 2111, the Uniform Prudent Investor Act, and other widely adopted fiduciary-oriented model laws. The article concludes with a discussion of implications for financial planning professors and students.
\end{abstract}

Keywords: Suitability; Fiduciary Standard; FINRA 2090; FINRA 2111; Financial Planning

\section{INTRODUCTION}

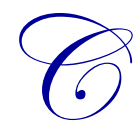

urrent policy debate in the financial planning industry involves the concepts of "fiduciary", "fiduciary standard", and "suitability". Several recent laws and regulations have added to the complexity. Students who intend to pursue careers in financial service professions, including wealth management, personal investment planning, and investment advising, need to have an understanding of these issues. The current paper provides an introduction to key concepts and regulations to help students understand current policy discussions and industry debates. Knowledge of these issues may also motivate students in their study of fields ancillary to finance, including business law, economics, and accounting.

\section{Fiduciary Standard And Suitability}

Students in business law and business ethics courses typically learn about fiduciary duties of agents; duties that arise out of the relationship of trust and confidence. They learn that a "fiduciary" means a personal representative or trustee. ${ }^{1}$ The investment profession uses similar definitions. For example, the fi360 organization ${ }^{2}$ describes the fiduciary relationship as "An investment fiduciary is someone who is managing the assets of another person and stands in a special relationship of trust, confidence, and/or legal responsibility. The word "fiduciary" comes from the Latin word "fiduciary," meaning "trust". An investment fiduciary is held to a standard of conduct and trust above that of a stranger or of a casual business person due to the superior knowledge and/or training of the fiduciary." 3

The relationship between customer and broker, long recognized as one of trust and confidence and fiduciary responsibility is codified in various laws and regulations, including Securities and Exchange Commission (SEC) and New York Stock Exchange (NYSE) rules. The Financial Industry Regulatory Authority, Inc. (FINRA), a

\footnotetext{
${ }^{1}$ http://www.uniformlaws.org/shared/docs/principal\%20and\%20income/upia_final_08.pdf Section 102(3)

2 fi360 provides the "Accredited Investment Fiduciary (AIF)" examination and certification to retirement plan advisers and other wealth managers and financial planners.

${ }^{3}$ http://www.fi360.com/fiduciary-resource-center/faq
} 
self-regulatory organization that engages in regulatory oversight of securities firms doing business in the U.S., issues regulations to assure the securities investment industry deals with customers in a fair and honest manner. ${ }^{4}$

After receiving SEC approval of its proposals related to "know-your-customer" and "suitability" obligations for its consolidated rulebook, FINRA issued Regulatory Notice 11-02 which provides guidance about these obligations. ${ }^{5}$ The new regulations, FINRA Rule 2090 (Know Your Customer) and FINRA Rule 2111 (Suitability) were designed to strengthen and clarify existing rules related to brokers' ethical responsibilities to deal knowledgably and fairly with customers. The initial implementation date of October 7, 2011 was extended to July 9, 2012 in order to respond to questions and concerns raised by the investment industry, many related to the suitability obligation, especially including questions about the expansion on types of information or data that brokers were expected to gather and review in determining "suitability."

FINRA Rule 2111 requires that in transactions with customers, the broker ("member or an associated person") "has a reasonable basis to believe that a recommended transaction or investment strategy involving a security or securities is suitable for the customer." "7 FINRA Rule 2111 Supplementary Materials Section .05 identifies three main suitability components or obligations: Reasonable-basis suitability, customer-specific suitability, and quantitative suitability. ${ }^{8}$

The standard for determining if the broker has met the reasonable-basis obligation is one of "reasonable basis to believe, based on reasonable diligence, that its recommendation is suitable for at least some investors" after review of factors such as risks associated with the particular security or investment strategy. The focus is on the broker; he or she must understand the security or strategy recommended. ${ }^{9}$

Customer-specific and quantitative suitability focus more on the particular investor. The standard for determining customer-specific suitability is one of "reasonable diligence" to ascertain the customer's "investment profile" and, from a review and analysis of that profile, has a reasonable basis to believe that a particular recommendation is suitable. Quantitative suitability also is determined in light of the customer's investment profile, the standard being whether the broker has a "reasonable basis for believing that a series of recommended transactions, even if suitable when viewed in isolation, is not excessive and unsuitable for the customer when taken together in light of the customer's investment profile..."10

The investment profile includes, but is not limited to, factors such as "the customer's age, other investments, financial situation and needs, tax status, investment objectives, investment expertise, investment time horizon, liquidity needs, risk tolerance, and any other information the customer may disclose to the member or associated person in connection with such recommendations." 11 While factors such as tax status, other investments, and the newly added factor of age, may be easily determined, other factors, including the newly added factors of time horizon, liquidity needs, and especially a customer's risk tolerance, are harder to assess, both by the broker and by the customer him or herself.

FINRA Regulatory Notice 11-25 attempted to respond to questions from investment firms related to what they needed to do to determine customer investment profiles but also recognized that customer preferences in terms of investment horizon, liquidity, and risk tolerance may conflict and be difficult to reconcile. Further, brokers cannot assume that customers with long-time horizons with ability to "wait out down cycles" will necessarily be seeking greater returns by taking on greater risk. ${ }^{12}$ The question remains, what is sufficient due diligence in determining a particular customer's risk tolerance? Further, how can an assessment of customer's risk tolerance be

\footnotetext{
${ }^{4}$ See, www.finra.org.

${ }^{5}$ FINRA Regulatory Notice 11-02, effective October 7, 2011.

${ }^{6}$ See, FINRA Regulatory Notice 11-25, effective July 9, 2012.

${ }^{7}$ FINRA Rule 2111(a).

${ }^{8}$ FINRA Rule 2111.05.

${ }^{9}$ FINRA Rule 2111.05(a).

${ }^{10}$ FINRA Rule 2111.05(b) and (c).

${ }^{11}$ FINRA Rule 2111(a).

${ }^{12}$ FINRA Regulatory Notice 11-25 FAQ 4.
} 
used to select specific assets and formulate appropriate portfolios? This is an active area of research, but there is currently no widely accepted answer.

\section{Uniform Prudent Investor Act And Related Laws}

Another key set of regulations includes the Uniform Prudent Investor Act (UPIA), ${ }^{13}$ the Uniform Prudent Management of Institutional Funds Act (UPMIFA), ${ }^{14}$ the Management of Public Employee Retirement Systems Act (UPERSA), ${ }^{15}$ and the Uniform Principal and Income Act. ${ }^{16}$ The Uniform Prudent Investor Act provides a foundation for these others which address specific applications of the fiduciary or trustee relationship. Consequently, it is informative to look at what criteria a financial fiduciary should additionally consider beyond the FINRA requirements previously discussed. In UPIA Section 2 ("Standard of Care; Portfolio Strategy; Risk and Return Objectives"), the following requirements are specified for investment managers under the act:

1. A trustee shall invest and manage trust assets as a prudent investor would, by considering the purposes, terms, distribution requirements, and other circumstances of the trust. In satisfying this standard, the trustee shall exercise reasonable care, skill, and caution.

2. A trustee's investment and management decisions respecting individual assets must be evaluated not in isolation but in the context of the trust portfolio as a whole and as a part of an overall investment strategy having risk and return objectives reasonably suited to the trust.

3. Among circumstances that a trustee shall consider in investing and managing trust assets are such of the following as are relevant to the trust or its beneficiaries:

a. General economic conditions;

b. The possible effect of inflation or deflation;

c. The expected tax consequences of investment decisions or strategies;

d. The role that each investment or course of action plays within the overall trust portfolio, which may include financial assets, interests in closely held enterprises, tangible and intangible personal property, and real property;

e. The expected total return from income and the appreciation of capital;

f. Other resources of the beneficiaries;

g. Needs for liquidity, regularity of income, and preservation or appreciation of capital; and

h. An asset's special relationship or special value, if any, to the purposes of the trust or to one or more of the beneficiaries.

4. A trustee shall make a reasonable effort to verify facts relevant to the investment and management of trust assets.

5. A trustee may invest in any kind of property or type of investment consistent with the standards of this [Act].

6. (f) A trustee who has special skills or expertise, or is named trustee in reliance upon the trustee's representation that the trustee has special skills or expertise, has a duty to use those special skills or expertise. ${ }^{17}$

While the concepts of fiduciary duty, such as the duties to account, to notify, to act with due care and skill and the duty of loyalty, are addressed, in general, in a number of business courses, specific applications relevant to investments and financial planning, especially including the UPIA and related laws, are not typically addressed in typical undergraduate level investment classes. For one thing, analyzing the specific impact of economic conditions on assets and their role within the portfolio is a potentially complicated analysis that is not explicitly addressed in any of the current leading investment textbooks. Second, the emphasis on evaluating each investment decision and asset within the context of the overall portfolio changes the investment focus from a "stock club" model, which selects investments asset by asset, to a portfolio-oriented approach which only selects assets that enhance the overall portfolio characteristics. Third, this act emphasizes the need for financial planning in addition to simply buying and

\footnotetext{
${ }^{13} \mathrm{http}: / /$ www.uniformlaws.org/shared/docs/prudent\%20investor/upia_final_94.pdf

${ }^{14} \mathrm{http}: / /$ www.uniformlaws.org/shared/docs/prudent $\% 20 \mathrm{mgt} \% 20 \mathrm{of} \% 20 \mathrm{institutional} \% 20 \mathrm{funds} /$ upmifa_final_06.pdf

${ }^{15} \mathrm{http}: / / \mathrm{www}$.uniformlaws.org/ActSummary.aspx?title=Management $\% 20$ of $\% 20$ Public\%20Employee\%20Retirement $\% 20$ Systems $\% 20 \mathrm{Act}$

${ }^{16} \mathrm{http} / / / \mathrm{www}$. uniformlaws.org/shared/docs/principal\%20and\%20income/upia_final_08.pdf

${ }^{17} \mathrm{http} / / /$ www.uniformlaws.org/shared/docs/prudent\%20investor/upia_final_94.pdf Section 2(a)-(f)
} 
selling stocks or mutual funds because of the need to understand needs for liquidity and cash flow. Finally, the fiduciary relationship is strengthened in that if a trustee has special skills or expertise, then the trustee has a legal duty to use those skills or expertise on behalf of her client.

\section{CONCLUSION}

This paper has provided an introduction to the current key regulations and laws defining the fiduciary and suitability standards. Whether the financial services industry will adopt an industry-wide fiduciary standard remains to be seen, but existing laws and regulations already require many, if not all, financial planners to act as fiduciaries, place their clients' interests above their own, use their full skills and expertise on behalf of their clients, perform significant analysis to relate each investment decision to the overall portfolio characteristics, and to analyze and incorporate the impact of the economy on individual assets and portfolios into their decision-making and documentation process. Just as those in the financial services industry are increasingly expected to understand legal and fiduciary responsibilities, so, too, such concepts must be included in relevant course curriculum.

\section{AUTHOR INFORMATION}

James T. Chong, Ph.D., is a Professor and Associate Director of the Center for Financial Planning and Investment at California State University, Northridge. He also serves as a Research Economist at MacroRisk Analytics. He received his Ph.D. in Finance from the ICMA Centre, The University of Reading. E-mail: jchong@csun.edu.

Penelope R. Jennings, J.D., is the Special Assistant to the Provost for Academic Personnel and a Professor of Business Law at California State University, Northridge. She received her J.D. from the UCLA School of Law. Email: penelope.jennings@csun.edu.

G. Michael Phillips, Ph.D., is the Director of the Center for Financial Planning and Investment and a Professor of Finance, Financial Planning, and Insurance at California State University, Northridge. He also serves as Chief Scientist for MacroRisk Analytics. He received his Ph.D. from the University of California, San Diego, with specializations in econometrics and applied economics. E-mail: mphillips@csun.edu (Corresponding author). 